\title{
An Availability Analysis of Fresh Fruit Bunches (FFB) by The Method of The Food Supply Chain Network (FSCN) PT. XYZ
}

\section{Andri Nasution, and Syarifah Yasmin Firiza}

Industrial Engineering Department, Faculty of Engineering, Universitas Sumatera Utara, Medan

\begin{abstract}
XYZ is a manufacturing company that is engaged in oil palm processing into Crude Palm Oil (CPO) and Crude Palm Kernel Oil (CPKO). Supply chain structure model adopted in PT. XYZ is the Mass Balance. Mass Balance is a supply chain model that allows a claim to be transferred from one certified palm oil products to other products either through physical blending or administratively under tightly controlled circumstances. nonfulfillment of processing capacity due to lack of supply of fruit coming into the plant from the garden supplier FFB does not reach the target supply to meet the plant's capacity. This will increase the cost per palm product so that profits earned by the company to be reduced because production capacity is not the same with a capacity / installed capacity owned by the manufacturer. Analysis of the results using the Food Supply Chain Network (FSCN) that causes a decrease in the availability of fresh fruit bunches (FFB) is influenced by the decreasing productivity of the garden as a supply based, which has been aged more than 20 years. Of the six aspects FSCN method, one aspect observed is the development of the supply chain and improvements to the supply-based to do the replanting of consideration to yield potential.
\end{abstract}

Keyword: CPO, CPKO, FSCN, and Forecasting

\begin{abstract}
Abstrak. PT XYZ adalah salah satu perusahaan manufaktur yang bergerak dalam bidang pengolahan kelapa sawit menjadi Crude Palm Oil (CPO) dan Crude Palm Kernel Oil (CPKO). Model struktur rantai pasok yang dianut pada PT. XYZ adalah Mass Balance. Mass Balance adalah model rantai suplai yang memungkinkan klaim bersertifikat untuk ditransfer dari satu produk kelapa sawit ke produk lainnya baik melalui pencampuran fisik atau secara administratif di bawah keadaan yang terkontrol ketat. Hal ini akan meningkatkan cost per palm product sehingga keuntungan yang diperoleh oleh perusahaan menjadi berkurang karena kapasitas produksi tidak sama dengan kapasitas olah / kapasitas terpasang yang dimiliki oleh pabrik. Dari hasilAnalisa menggunakan metode Food Supply Chain Network (FSCN) didapatkan bahwa penyebab penurunan ketersediaan tandan buah segar (TBS) di pengaruhi oleh menurunnya produktifitas dari kebun sebagai supply based yang sudah berumur lebih dari 20 tahun. Dari enam aspek metode FSCN, salah satu aspek yang sangat diperhatikan adalah aspek pengembangan terhadap rantai pasokkan dan perbaikan terhadap supply based dengan melakukan replanting atas dasar pertimbangan terhadap potensial yield.
\end{abstract}

Kata Kunci: CPO, CPKO, FSCN, danPeramalan

Received 28 January 2020 | Revised 25 February 2020 | Accepted 27 February 2020

\footnotetext{
*Corresponding author at: Industrial Engineering Department, Faculty of Engineering, Universitas Sumatera Utara, Medan, Indonesia 


\section{Introduction}

PT. XYZ is a company engaged in the manufacture of Crude Palm Oil (CPO) and Crude Palm Kernel Oil (CPKO). Basically, this plant has a supply chain structure that is Mass Balance.Mass Balanceis a supply chain model that allows a claim to be transferred from one certified palm oil products to other products either through physical blending or administratively under tightly controlled circumstances. The structure of the supply chain (supply chain) in a company may cause problems if the company does not know all the information and the smoothness of the performance of the supply chain that have been applied in the enterprise

Problems faced by the factory at PT. XYZ is not meeting the installed capacity (maximum) because of the minimal supply of fruit from FFB supplier gardens. The supplier's farm did not reach the target in meeting the optimum FFB processing capacity at the mill. This would increase the cost per palm product so that the profits from the company would be reduced because the production capacity was not the same as the installed capacity.

In brief, within an FSCN we identify one or more Chain Business Processes withwell-identified products that are produced and delivered to the customer of thatChain Business Process (e.g. chain processes that produce and deliver boxes withyoghurt or cheese slices to retail outlets). These production and delivery processesrequire the execution of business activities by one of the actors participating in thenetwork (such as transportation, storing, order picking). There are precedencerelations between business activities that are or may be determined by goods,resources, information, financial and control flows. So we may regard an FSCN as adirected network of business processes and activities with precedence relationships. [1]

Nurmalina, Rifin, Harmini, \& Amalia (2013) add that improvements to the marketing fieldby reducing marketing and creating costsselling price in accordance with purchasing powerconsumers can increase marketing efficiency.[2] According to Qhoirunisa (2014) the performance of the supply chain structure can be analyzed qualitatively, including in analyzing the performance or the resulting performance. Qualitatively supply chain performance analysis needs to be supported by quantitative performance measures in order to produce more measurable and objective performance results. As an integrated process between members who are members of it, the measurement of supply chain performance needs to use a certain approach. [3] Supply chain performance is defined by Christien et al (2006) as a meeting point between consumers and stakeholders where both conditions have been met with the relevance of the performance indicator attributes over time.[4]

Troubleshooting performed using the Food Supply Chain Network (FSCN). FSCN supply chain analysis method that can be evaluated in the context of network complex food supply chain. 
Based on the analysis conducted found several obstacles that led to the supply of FFB declined in recent years.

\section{Research Methods}

This study started from collecting data with the process of observation, and documentation. Data collected is data required by the literature that became the foundation. The result of the processing of such data would then be concluded and provided solutions to these problems.observations were made in July to August 2019 at PT. XYZ Variables in this study are recapitulation of $\mathrm{CPO}$ and $\mathrm{CPKO}$ production data, recapitulation of fresh fruit bunches supply data, data on plantations covering area, plant age, and distance from plantation to factory, And product flow data, information and costs at PT. XYZ.

\section{Analysis and Discussion}

Problems faced by the factory at PT. XYZ is not meeting the installed capacity (maximum) because of the minimal supply of fruit from FFB supplier gardens. The supplier's farm did not reach the target in meeting the optimum FFB processing capacity at the mill. This would increase the cost per palm product so that the profits from the company would be reduced because the production capacity was not the same as the installed capacity. While the price of CPO can not be set by the company based on cost and margin but follow the market price.

Table 1. Comparison of Production Target CPO with CPO Production Achieved

\begin{tabular}{ccc}
\hline Year & Production & Target \\
\hline 2015 & $72,087,860$ & $77,990,606$ \\
2016 & $65,369,930$ & $75,482,463$ \\
2017 & $62,767,830$ & $68,600,565$ \\
2018 & $22,144,255$ & $23,007,770$ \\
\hline
\end{tabular}

The following is a comparison chart between CPO production target set by the CPO production reached. 


\section{Comparison of Total Production Target CPO with CPO \\ production achieved in $2015-2018$}

1.000 .000 .000

100.000 .000

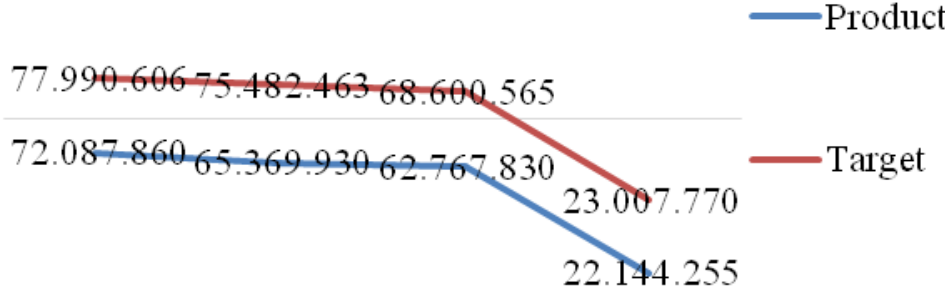

10.000 .000

$2015 \quad 2016 \quad 2017 \quad 2018$

Figure 1 Comparison of Total Production Target CPO with CPO production achieved in $2015-2018$

The chart can be seen on production and production targets achieved each year has dropped significantly, with the most drastic decline in 2018, with a target reduction of $30 \%$ and a decline in production by 35\%. Here's a garden plant age data core that is part of the nucleus (core KBN)

Table 2 Core Data Plant Age KBN

\begin{tabular}{ccc}
\hline Information & REPL. / NON REPL. & Ha \\
\hline RPL & REPL. & 16 \\
& REPL. & 65 \\
& REPL. & 171 \\
& REPL. & 233 \\
& TOTAL PLANT replanting & $\mathbf{4 8 5}$ \\
\hline TM & NON REPL. & 21 \\
& NON REPL. & 171 \\
& NON REPL. & 299 \\
\hline & NON REPL. & 551 \\
\hline TBM & TOTAL PLANT PRODUCES & $\mathbf{1 0 4 2}$ \\
\hline TOTAL PLANT HAS NOT PRODUCE & $\mathbf{7 3 5}$
\end{tabular}


Here's a crop age data Gardens New Overseas (KRB) which is part of the Own Garden PT. XYZ

Table 3 Data Age New Overseas Plants Gardens (KRB)

\begin{tabular}{cc}
\hline year of Planting & Area (Ha) \\
\hline 1991 & 605 \\
1992 & 460 \\
1994 & 496 \\
1998 & 1837 \\
1999 & 755 \\
2000 & 596 \\
2005 & 132 \\
2008 & 434 \\
2009 & 124 \\
\hline TOTAL & $\mathbf{5 4 3 9}$ \\
\hline
\end{tabular}

Based on the analysis conducted found several obstacles that led to the supply of FFB declined in recent years, it was found that the age factor is one of the factors that caused the crop continues to decline, the average age of the plant more than 20 years and had entered menopause and still in The first generation of garden plants. This causes the production of a few years the target is not achieved.

Troubleshooting performed using the Food Supply Chain Network (FSCN). FSCN supply chain analysis method that can be evaluated in the context of complex network food supply chain,The method of analysis refers to the framework of the development of the supply chain Food Supply Chain Networking (FSCN) examines six areas in which structured namely:

1. Target supply chain

The objective aspect of the supply chain aims to explain achievement in the supply chain of fresh fruit bunches to PT. XYZ. Aspects of the supply chain target is seen from two things, namely the target market and development objectives. Two aspects of this is a reference to the smooth supply chain structure.

\subsection{Target Markets}

Target market supply chain PT. XYZ is the achievement of the ideal conditions related to the supply of raw material FFB in accordance with installed capacity (maximum capacity) plant is 60 tonnes FFB per hour, it can not be separated from the supply of garden suppliers as supply based, which has a number fluctuates and the smooth factory in processing the FFB. It aims to obtain consumer satisfaction and put the consumer as a very important object. 


\subsection{Development Goals}

Target development in the supply chain is used as the cornerstone of efforts to develop various aspects of improved performance of the chain. Such efforts are considered essential to the improvement of the performance of the chain with coordination and good relations between the elements in a supply chain. Development can be done by strengthening in some sectors, such as sector strengthening the supply chain availability of raw materials supply based or garden as partners to support the fulfillment of the installed capacity in the plant and make the effort of strengthening the coordination between all the elements to build a good information system in the supply chain so that the flow of the supply chain running smoothly without a hitch. The decline in CPO production due to unfulfilled capacity installed plant. Non-fulfillment of installed processing capacity of the plant caused by decreasing the amount of supply of FFB. it is the impact of the age of the plant is old and no longer able to produce good fruit. For the first generation of plants must be replanting.

2. The structure of the supply chain

The structure of the supply chain which is owned PT.XYZ starting from upstream (supply based) to downstream (consumers) as well as the relationship described and linked to the presence of elements - elements of the supply chain as well as other forms of cooperation that took place between several parties (elements) within the enterprise supply chain , Here is an arrangement of the supply chain structure in PT. XYZ

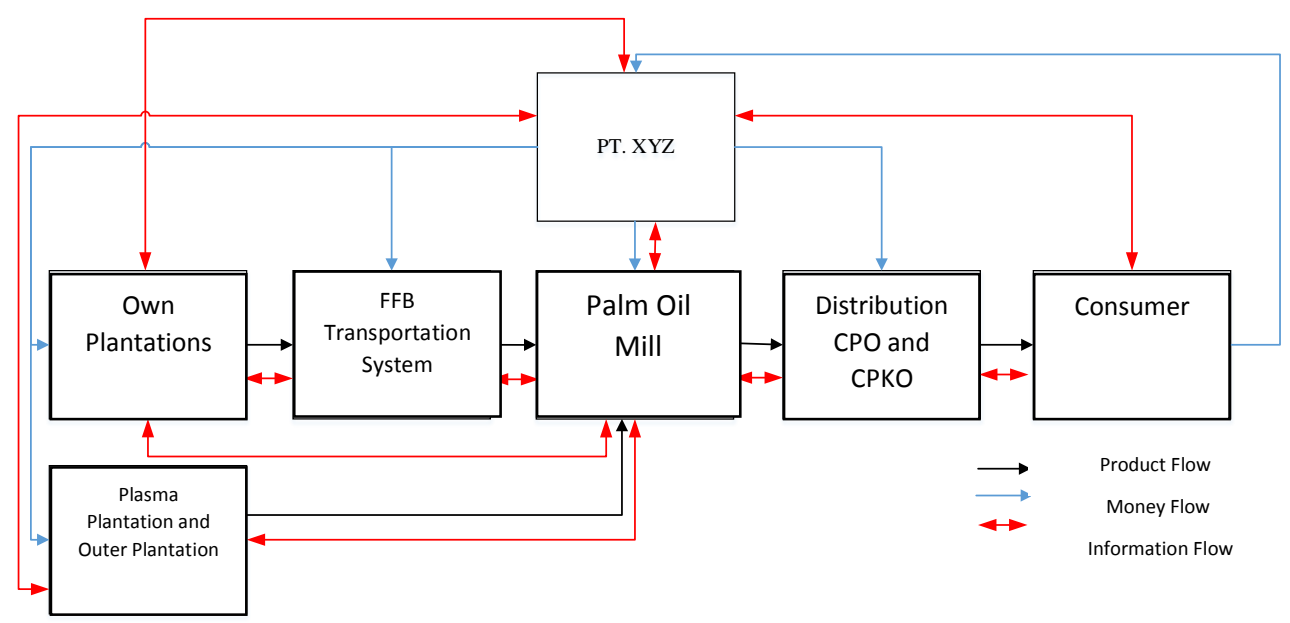

Figure 2. Structure of Supply Chain PT. XYZ 
3. Supply resources

Supply resources consist of several resources that compose a supply chain that includes physical resources FFB availability of garden suppliers and other resources such as physical resources, human, and information technology.

\subsection{Physical Resources}

Physical resources owned by PT. XYZ covers a factory with an area of 10 hectares, with installed plant capacity of 60 tons/hour. The factory is this also comes with a variety of tools that help FFB become a CPO processing so that the processing is done with modern processing methods. The entire oil palm being based supply consists of 60,000 ha, but particularly Afdelling 1,2,3, and 8 is a major supplier to the PMKS. Farthest distance garden to plant is $14 \mathrm{KM}$. Area environmental conditions tended garden hilly but has a condition good roads and good transportation.

\subsection{Technology Resources}

Technological resources used to assist the production process from beginning to end. The technology used in the form of machinery and equipment that the latest technology with the help of trained workers so that the production process can run effectively and efficiently.

\subsection{Human Resources}

One important component of the company is human resources. Humans as workers who helped in the production activities at PT. XYZ numbering 135 persons include factory workers and office workers.

4. Chain management

Chain management is amanagement process and coordination are done from scratch (supply based) until the product is received by consumers. Chain management in this company covers all the relationships between each element in the supply chain, tendering, agreements with partners, and distribution system is structured.

5. Business Process Chain

Chain business process is a process that includes the chain in the business process chain. Distribution pattern is a component contained in the business chain process which is divided into product flow, cash flow, and the flow of information.

\subsection{Product flow}

The product stream flow is passed in the production process of supply based (Gardens). The flow of the product stream supply chain of fresh fruit bunches (FFB) is as follows. 


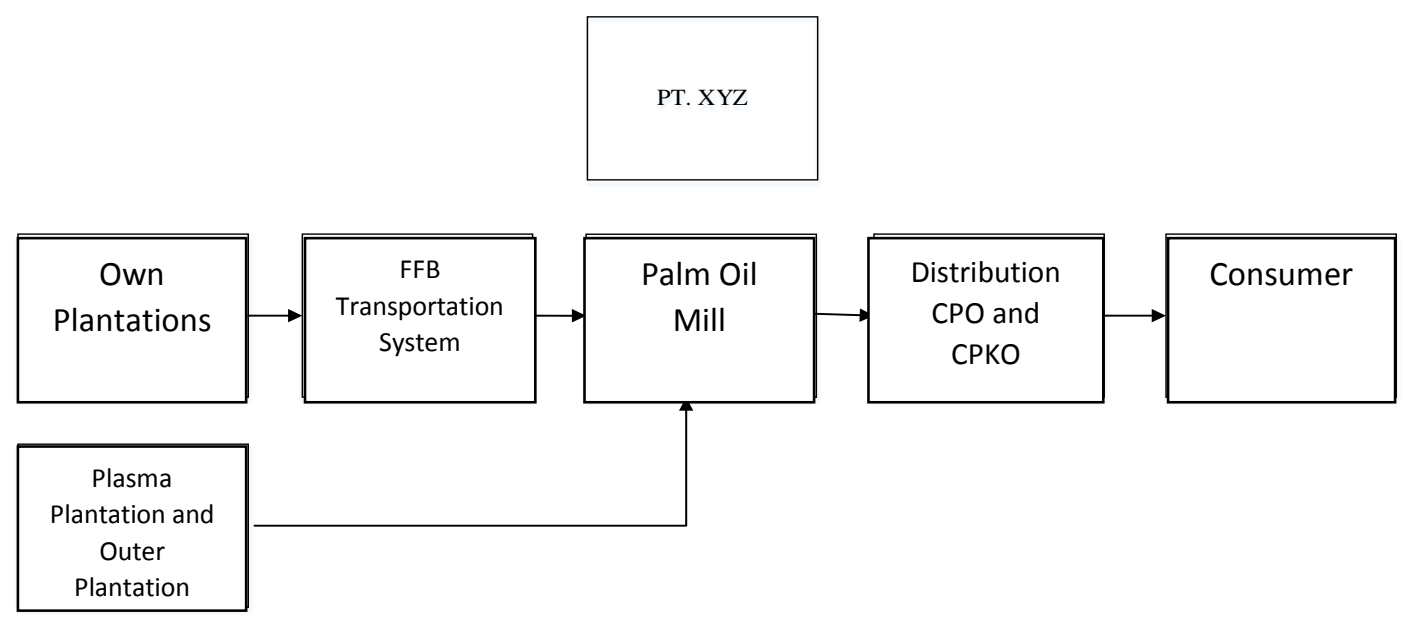

Figure 3. Flow Products On Supply Chain FFB PT. XYZ

The flow of products on the chain of supply FFB starting from the third garden, the Garden Alone, Plasma Estate and Gardens Affairs, then FFB has given cards to PMKS weigh transported by truck. FFB incoming then weighed and checked for weight card then do the sorting in the sorting station and then proceed with the processing performed by PMKS. The finished product in the form of oil that has been completed is processed and passed the quality test will be stored in tanks. Third party which is the party will distribute and guarantee the distibution of CPO and CPKO from PT. XYZ up to the consumer in the country and abroad.

\subsection{Money flow}

Money or fund an initial capital in the sustainability of the production process.

Capital is considered essential supply chain flow. Here is the flow of money in the supply chain distribution of fresh fruit bunches (FFB).

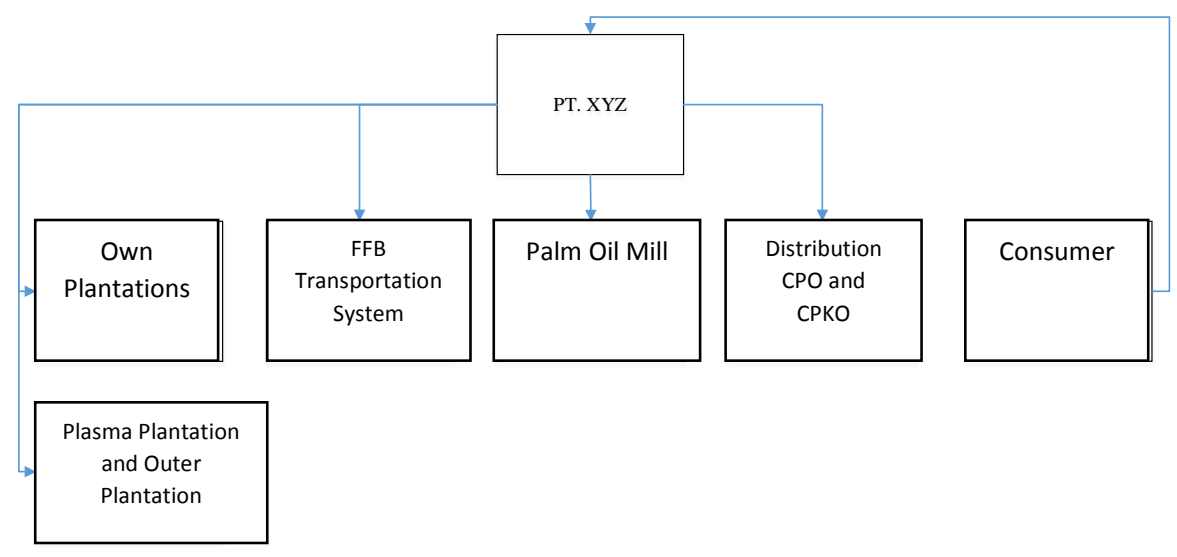

Figure 4. Flow of Money Supply Chain FFB PT. XYZ

PT. XYZ will receive payment of the tender or the order from the consumer in the country or abroad where the money will be distributed to the people's own gardens and smallholdings as capital maintenance and planting. The money will also be paid 
to people who have been supplying FFB on PMKS. PT. XYZ make payments to the wage distribution from the garden to PMKS and distribution fee payments to third parties as a supplier of products to consumers.

5.3. Information flow

Information flow is a very important component of maintaining the continuity of a chain pasokkan. Distribution of good information will create a healthy supply chain with good management and good coordination would avoid a potentially miss the ongoing communication activities in the supply chain.

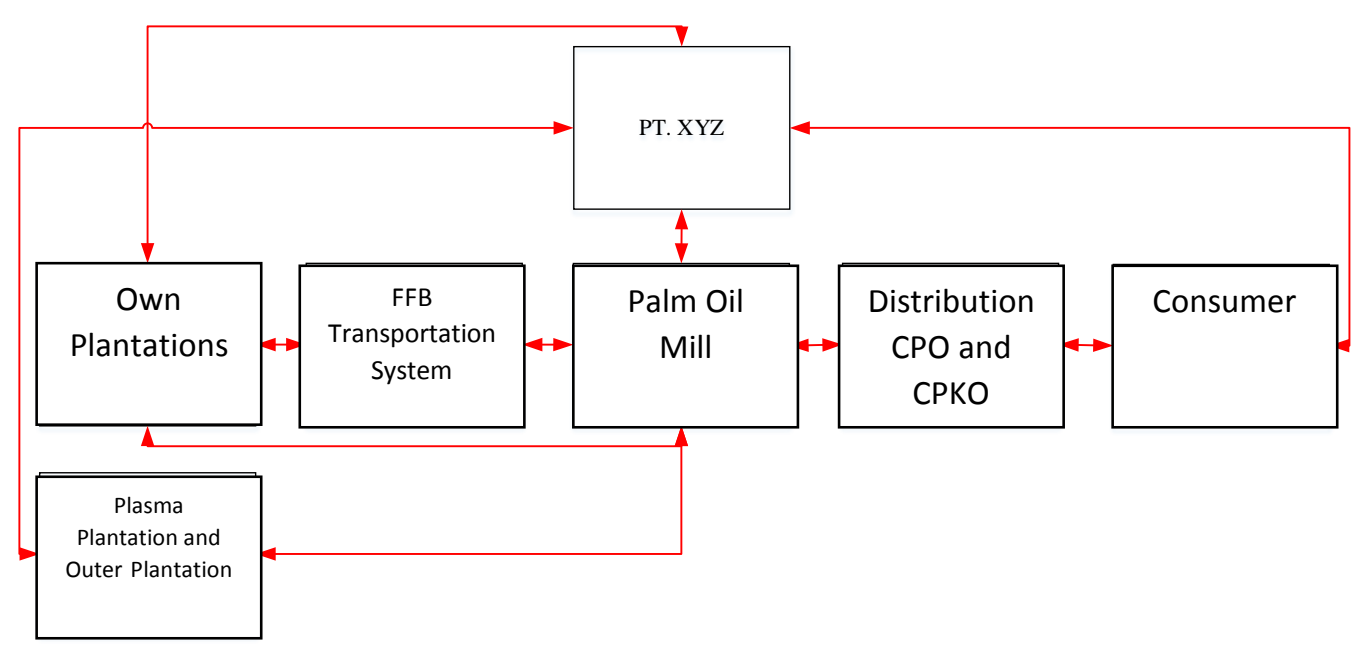

Figure 5. Money Flow Supply Chain FFB PT.XYZ

The flow of information in the supply chain on PT. XYZ consists of preliminary information on ordering by consumers who are then submitted to the PMKS to be made in production and PMKS baselines will provide information about the achievement of CPO and CPKO, stock number, and daily reports of factory production. PT. XYZ will provide information about the target from farm production announced by the company, while the garden will provide information such as the realization of the achievement of farm production through production daily reports gardens. PT. XYZ also provide information about the supply targetof the Plasma Estate and Gardens Affairs. PMKS receive information in the form of realization of pasokkanFFB coming from the garden and also provide information on receiving FFB brought from the garden. The distribution system receive the transport schedule information, and relay information about FFB carries the card carrying stations. PMKS will provide information to third parties or distributors to do the distribution of products after the completion complete the order. Distributor or third party will provide information to consumers as well as PT. XYZ regarding the distribution schedule. Lastly, consumers will provide information on the acceptance of products, complaints, criticisms or suggestions. 
6. Supply chain performance

Performance of supply chain used to assess whether it is run in accordance with the roles and their respective portions by being able to improve the effectiveness and efficiency of the plant to produce CPO. But the implementation has not been effective due to the productivity of the factory continued to decline seiiring with increasing years. Many factors can improve the performance of supply chain back to do some evaluation of each element - element that supports supply chain CPO and CPKO PT. XYZ.

\section{Conclusions}

The conclusions derived from this research are as follows.

1. The decline in CPO production due to unfulfilled installed plant capacity. Non-fulfillment of installed processing capacity of the plant caused by the declining number of Supply FFB. it is the impact of the age of the plant is old and no longer able to produce good fruit. For the first generation of plants must be replanting.

2. Development can be done by strengthening in some sectors, such as the strengthening of the supply chain sector availability of raw materials supply based or garden as partners to support the fulfillment of installed production capacity.

3. FFB supply constraints which led to decline in recent years, it was found that the age factor is one of the factors that caused the crop continues to decline, the average age of the plant more than 20 years and has entered menopause.

\section{REFERENCES}

[1] J. G. A. J. V. D. Vorst, "Performance Measurement in Agri-Food Supply Chain Networks.”

[2] R. Nurmalina, R. Rifin, A. Harmini, and N. D. Amalia, "Kajian pemasaran karet rakyat di Provinsi Jambi”, Prosiding Seminar Penelitian Unggulan Departemen Agribisnis, 2013.

[3] A. Qhoirunisa, "Rantai Pasok PadiDi Kabupaten Bogor Jawa Barat”, Thesis, IPB, 2014.

[4] Christien, et al, "Quantifying theAgri Food Supply Chain”, Springer International Publisher Science, 2006. 